\title{
TATALAKSANA ANESTESI DAN REANIMASI \\ PADA OPERASI OTITIS MEDIA EFUSI
}

\author{
Dewa Ayu Putu Diah D \\ Fakultas Kedokteran Universitas Islam Al-Azhar \\ Rumah Sakit Umum Daerah Bangli - Bali
}

\begin{abstract}
ABSTRAK
Operasi Telinga, Hidung dan Tenggorokan (THT) adalah operasi yang paling umum dilakukan dan sangat sering membutuhkan ahli bedah dan anestesi untuk berbagi ruang kerja yang sama. Karenanya komunikasi antara kedua pihak sangat penting. (George, 2014). Prosedur telingahidung-tenggorokan (THT) merupakan prosedur yang unik dikarenakan antara anestesiologis dan operator berbagi jalan nafas. Pengelolaan anestesi pada pasien berpusat pada pengaturan jalan nafas. Kerjasama dan komunikasi antara operator dan anestesiologis menjadi lebih penting dibanding pembedahan pada wajah dan leher. ( Donlon, 2000). Myringotomymerupakan tindakan pembedahan pada membrane timpani, untuk mengeluarkan tekanan berlebih didalam telinga tengah yang diakibatkan oleh supurasi cairan atau tekanan udara. (Dorland, 2006).
\end{abstract}

Kata Kunci : General Anastesi, Face Mask, Myringotomy.

\section{PENDAHULUAN}

Anestesiologi adalah cabang ilmu kedokteran yang mendasari berbagai tindakan meliputi pemberian anestesi, penjagaan keselamatan penderita yang mengalami pembedahan, pemberian bantuan hidup dasar, pengobatan intensif pasien gawat, terapi inhalasi dan penanggulangan nyeri., (dorland, 2006).

Tindakan anastesi berarti memberikan pelayanan anastesia umum pada pasien yang akan dilakukan pembedahan yang meliputi trias anastesia yakni hipnotik ( tidak sadarkan diri=mati ingatan), analgesia (bebas nyeri=mati rasa), relaksasi otot rangka (mati gerak).

Akibat pengaruh obat anastetikum yang menimbulkan efek trias anastesiall pasien akan mengalami koma (tidak sadar), reflek-reflek proteksi menghilang akibat mati rasa dan kelumpuhan otot rangka termasuk otot pernafasan, sehingga pasien sangat memerlukan tindakan bantuan kehidupan selama prosedur anastesi/ bedah berlangsung, yakni reanimasi/resusitasi atau bantuan nafas., (Agung. 2017).

Operasi Telinga, Hidung dan Tenggorokan (THT) adalah operasi yang paling umum dilakukan dan sangat sering membutuhkan ahli bedah dan anestesi untuk berbagi ruang kerja yang sama. Karenanya komunikasi antara kedua pihak sangat penting., (George, 2014).

Prosedur Telinga Hidung Tenggorokan (THT) merupakan prosedur yang unik dikarenakan antara anestesiologis dan operator berbagi jalan nafas. Pengelolaan anestesi pada pasien berpusat pada pengaturan jalan nafas. Kerjasama dan komunikasi antara operator dan anestesiologis menjadi lebih penting disbanding pembedahan pada wajah dan leher., ( Donlon, 2000). 
Beberapa jenis analgesi diperlukan pada seluruh anak yang diobati tanpa rawat inap. Derkay dkk menemukan bahwa dapat digunakan tetes telinga saat operasi yang telah dicampur dengan $4 \%$ lidokain, penggunaan analgesik oral preoperasi dapat memberikan sedikit manfaat. Pemberian oral preoperasi berupa acetaminofen, atau acetaminophen dengan codein, dan bahkan buthorphanol intranasal direkomendasikan sama efektifnya., (david, 2012)

Myringotomy merupakan tindakan pembedahan pada membrane timpani, untuk mengeluarkan tekanan berlebih didalam telinga tengah yang diakibatkan oleh supurasi cairan atau tekanan udara., (Dorland, 2006).

Membran timpani adalah sebuah membran tipis yang sedikit oval yang mengakhiri liang telinga. Berbentuk kerucut dengan tinggi $2 \mathrm{~mm}$ serta apeks yang mengarah kedalam. Terlihat dari liang telinga luar, membrane ini sedikit cekung dan digantung oleh cincin tulang. Secara normal membran ini berada pada tegangan tertentu. Luas permukaan nya kira-kira $85 \mathrm{~mm}^{2}$. Bagian utama dari membran timpani adalah pars tensa dengan area kira-kira seluas $55 \mathrm{~mm}^{2}$, yang tersusun atas serat-serat sirkuler yang saling tumpang tindih. Serat-serat ini tersusun atas kolagen dan membentuk membran kaku yang ringan sehingga ideal untuk mengubah gelombang suara menjadi getaran pada tulang malleus. Bagian lebih kecil dari membran timpani adalah pars flaccida, terletak diatas Manubrium Malleus, lebih tebal dari pada pars tensa dan serat-seratnya tidak tersusun baik seperti serat-serat kolagen pada pars tensa. Membran timpani di lapisi oleh selapis sel epidermis, yang merupakan lanjutan dari liang telinga. Bagian luar membrane timpani ini bermigrasi dari tengah ke bagian luar dan memindahkan luka kecil dan parut serta mentransport benda asing kecil keluar ke liang telinga. Lubang kecil pada membran timpani biasanya akan sembuh spontan., (Moore, 2006).

Otitis Media Kronis (OM) ditandai dengan demam dan sakit telinga (baik ada atau tidak discharge telinga) dan sering terjadi pada anak-anak. Ini sering terjadi dan berhubungan dengan saluran pernapasan atas baik berasal dari virus atau bakteri. Dalam banyak kasus OM merespon merespon antibiotik, namun infeksi berulang biasanya memerlukan operasi, yang memerlukan pembuatan sebuah lubang di gendang telinga (miringotomi) untuk mengurangi tekanan dan mengalirkan sekresi telinga tengah., (David, 2012).

Membuat, memelihara dan menjaga jalan nafas pada kondisi anatomi yang abnormal dan intervensi pembedahan yang simultan dapat menguji ketrampilan dan kesabaran ahli anestesi. Tepatnya 
pengetahuan mendalam tentang anatomi jalan nafas dan apresiasi umum prosedur THT akan membuktikan betapa bernilainya hal tersebut dalam menangani tantangan para ahli anestesi ini., (David, 2012).

Penelitian terbaru tentang pertanggungjawaban medis mengklaim melalui American Society of Anesthesilogist, bahwa faktor kesalahan manusia masih menjadi penyebab terbanyak kematian dalam anestesi; masalah jalan nafas menyumbang lebih dari $30 \%$ kasus pada orang dewasa dan 43\% kasus pada anak., (Donlon, 2000).

\section{INVESTIGASI}

\section{Anamesis}

Pasien perempuan usia 39 tahun datang sadar ke RSU Bangli dengan keluhan telinga terasa tersumbat dan penurunan pendengaran pada telinga kanan. Keluhan dirasakan sudah cukup lama sekitar satu tahun belakangan. Pasien mengatakan keluhan telinga tersumbat dirasakan terus menerus setiap hari dan semakin memberat sehingga pasien merasa kurang pendengaran bahkan sampai kadang-kadang tidak dapat mendengar. Pasien mengatakan keluhan dirasakan secara tiba-tiba sekitar satu tahun yang lalu dan perlahan- lahan dirasakan semakin memberat dan mengganggu aktivitas. Pasien juga mengatakan sejak beberapa hari ini telinganya terasa nyeri yang dirasakan secara terus menerus dan mengganggu pasien. Pasien mengatakan keluhantidak membaik baik saat istirahat ataupun beraktivitas. Pasien tidak pernah megalami keluhan yang sama sebelumnya. Keluhan lain seperti batuk, pilek, pusing disangkal.

\section{Pemeriksaan Fisik}

$\underline{\text { Status Generalis }}$

Keadaan Umum : Baik

Kesadaran : Compos mentis

Berat Badan : $63 \mathrm{~kg}$

Tekanan Darah $\quad: 110 / 80 \mathrm{mmHg}$

Nadi $\quad: 80 \mathrm{x} / \mathrm{menit}$

Respirasi : $20 \mathrm{x} / \mathrm{menit}$

Suhu $\quad: 36.2^{\circ} \mathrm{C}$

NRS : 2

\section{B1 (Brain) : E4 V5 M6}

- Kepala : Normocephal

- Mata : Konjungtiva tidak anemis, sclera tidak ikterik, kedua pupil isokor.

B2 (Breath) :

- Inspeks : Bentuk simetris, gerak pernafasan statis dan dinamis

- simetris, tetraksi sela iga (-).

- Palpasi : Fremitus vocal dan taktil simetris kanan dan kiri, tidak

- teraba massa, krepitasi (-)

- Perkusi : Sonor diseluruh lapang paru

- Auskultasi : Suara nafas vesikuler, ronkhi -/-, wheezing -/-.

B3 (Blood) : 
- Inspeksi

: Iktus kordis

tidak terlihat

- Palpasi

: Pulsasi iktus

kordis teraba sela iga kelima linea midklavikuka sinistra

- Perkusi : Batas jantung kiri sela iga $\mathrm{V}$ line midklavikula sinistra,

- Batas jantung kanan sela iga V linea parasternal dextra,

- Batas pinggang jantung sela iga II linea parastelnal sinistra.

- Auskultasi : Bunyi jantung I - II reguler, tidak ditemukan gallop maupun murmur.

B4 (Blader) : Urine Spontan, kateter terpasang

\section{B5 (Bowel)}

- Inspeksi : Perut simetris kanan dan kiri, datar, tidak ada ditemukan

- sikatrik dan massa.

- Auskultasi : Bising usus (+) $8 \mathrm{x} /$ menit menurun.

- Palpasi : Nyeri tekan (+) Mc Burney. Turgor kulit baik hepar tidak teraba mebesar.

- Perkusi : Terdengar timpani pada seluruh lapang abdomen

B6 (Bone) : Akral hangat, fraktur (-).

\section{LEMON}

- Look eksternal : Trauma wajah (-), Lebar jarak gigi seri dan bawah normal, Lidah lebar (-), Obesitas (-)

- Evaluated

- Jarak gigi seri atas dan bawah 3 jari
- Jarak hyoid mental 3 jari

- Jarak hyoid thyroid 2 jari

- Mallampati : Skor 1

\section{Pemeriksaan Laboratorium}

\begin{tabular}{|c|c|c|}
\hline $\begin{array}{l}\text { Jenis } \\
\text { Pemeriksaan }\end{array}$ & Hasil & $\begin{array}{l}\text { Nilai } \\
\text { Rujukan }\end{array}$ \\
\hline Leukosit & 8,6 & $3.5-10 / \mathrm{uL}$ \\
\hline Hemoglobin & 14,9 & $12-16 \mathrm{~g} / \mathrm{dL}$ \\
\hline Hematokrit & 44,2 & $37-47 \%$ \\
\hline Eritrosit & 5,24 & $\begin{array}{l}4,3-6,0 \\
\text { juta/uL }\end{array}$ \\
\hline Trombosit & 278. & $150-400 / \mathrm{uL}$ \\
\hline $\mathrm{MCV}$ & 84,3 & $75-100 \mathrm{fl}$ \\
\hline $\mathrm{MCH}$ & 28,4 & $25-35 \mathrm{pg}$ \\
\hline $\begin{array}{l}\text { MCHC } \\
\text { Faal } \\
\text { Hemostasis } \\
\text { Waktu } \\
\text { Perdarahan } \\
\text { Waktu } \\
\text { Pembekuan }\end{array}$ & $\begin{array}{l}1^{\prime} 30 \\
\| \\
8^{\prime} 300 \\
\|\end{array}$ & $\begin{array}{l}1-3 \text { menit } \\
1-6 \text { menit }\end{array}$ \\
\hline
\end{tabular}

Berdasarkan anamnesis, pemeriksaan fisik dan pemeriksaan penunjang, maka didapatkan :

- Diagnosis pre operatif : Otitis Media Eksudatif Dextra

- Status operatif : Status Fisik ASA I

- Jenis operasi : Myringotomy

- Jenis anestesi : General Anastesi Face Mask 


\section{TATALAKSANA}

Saat pasien berada di ruangan preoperasi, pasien diberikan obat - obatan premedikasi, yaitu :

Sedative : Midazolam 0,05-0,1 $\mathrm{mg} / \mathrm{KgBB} \quad \rightarrow 1 \mathrm{mg}$ (IV)

Analgetik : Ketorolac $0,5 \mathrm{mg} / \mathrm{KgBB}$ $\rightarrow 30 \mathrm{mg}$ (IV)

Antiemetik : Ondancentron $0,05-0,1$ $\mathrm{mg} / \mathrm{KgBB} \quad \rightarrow 1 \mathrm{mg}$ (IV)

Ranitidine $1-2 \mathrm{mg} / \mathrm{KgBB} \quad \rightarrow 15 \mathrm{mg}$ (IV)

- Pasien dibaringkan di meja operasi

- Pemberian obat-obatan induksi :

Fentanyl 1-2 $\mu \mathrm{g} / \mathrm{KgBB}$

$\rightarrow 15 \mu \mathrm{g}$ (IV)

Propofol 2-2,5mg/KgBB

$$
\rightarrow 30 \mathrm{mg} \text { (IV) }
$$

- Oksigenasi dengan O2 6-10 liter/menit

- Memompa nafas pasien sesuai dengan frekuensi nafas normal $( \pm 14-18$ kali per menit).

- Maintenance dengan sevoflurance $2 \%$, N20 70\%, dan O2 30\%

- Setelah operasi selesai, melakukan pembersihan jalan nafas dari sekret dengan menggunakan suction.

- Ekstubasi ET setelah os bernafas spontan.

\section{a. Pemantauan Selama Anestesi}

Melakukan monitoring secara kontinue tentang keadaan pasien yaitu reaksi pasien terhadap pemberian obat anestesi khususnya terhadap fungsi pernapasan dan jantung.

\begin{tabular}{|c|c|c|c|c|}
\hline Jam & Tindakan & $\begin{array}{c}\text { Tekanan } \\
\text { Darah } \\
(\mathrm{mmHg})\end{array}$ & $\begin{array}{c}\text { Nadi } \\
(\mathrm{x} / \mathrm{me} \\
\text { nit })\end{array}$ & $\begin{array}{c}\text { Sat } \\
\text { uras } \\
\mathrm{i} \text { O2 } \\
(\%)\end{array}$ \\
\hline 11.30 & 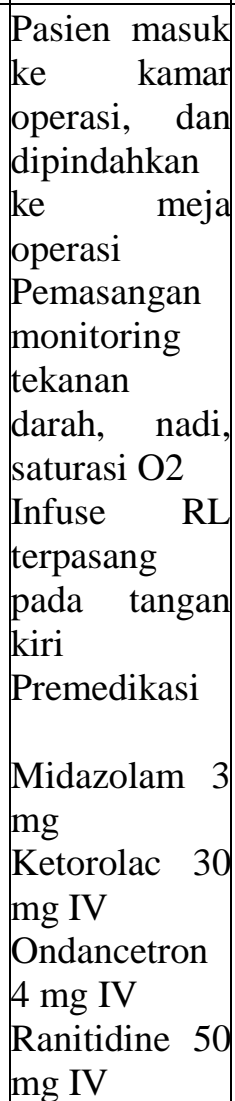 & A & 80 & 100 \\
\hline 11.45 & 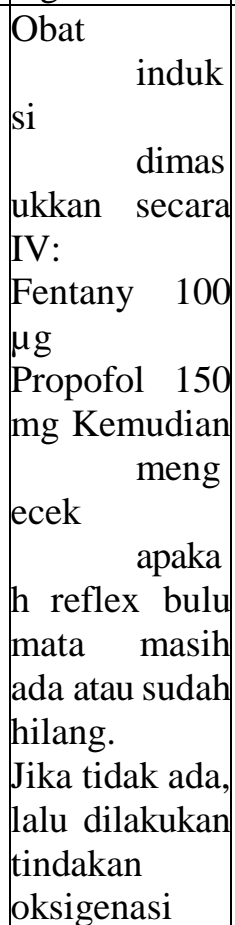 & $110 / 75$ & 68 & 100 \\
\hline
\end{tabular}




\begin{tabular}{|c|c|c|c|c|}
\hline & $\begin{array}{l}\text { dengan face } \\
\text { mask dengan } \\
\text { sungkup no. 3, } \\
\text { dengan teknik } \\
\text { jaw thrust }\end{array}$ & & & \\
\hline 11.50 & 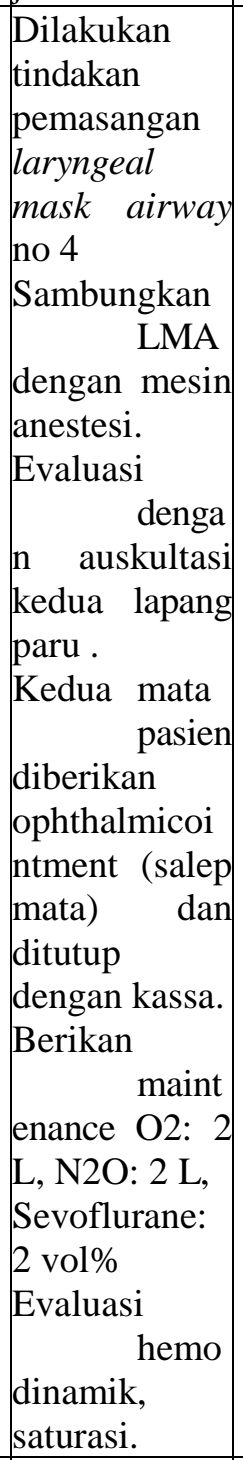 & $110 / 80$ & 70 & 99 \\
\hline 11.55 & \begin{tabular}{|l|} 
Operasi \\
dimulai \\
Kondisi \\
terkendali
\end{tabular} & $110 / 80$ & 79 & 100 \\
\hline 12.45 & $\begin{array}{l}\text { Kondisi } \\
\text { terkendali } \\
\text { Miringotomi } \\
\text { selesa } \\
\text { i dilakukan }\end{array}$ & $115 / 67$ & 81 & 100 \\
\hline 12.50 & \begin{tabular}{|l|} 
Melakukan \\
ekstubasi saat \\
pasien \\
sadar \\
memperhatika
\end{tabular} & $110 / 70$ & 75 & 100 \\
\hline
\end{tabular}

\begin{tabular}{|c|}
\hline 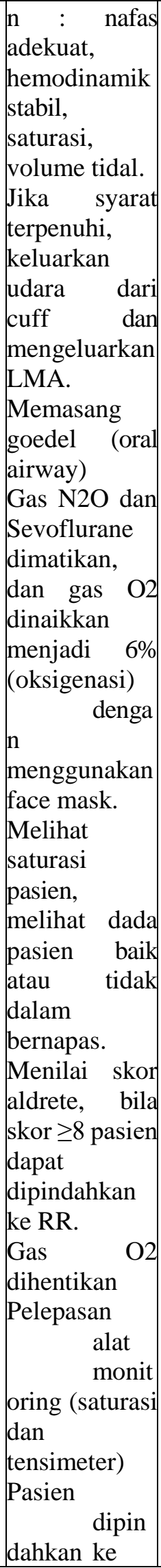 \\
\hline
\end{tabular}




\begin{tabular}{|c|c|c|c|c|}
\hline & $\begin{array}{l}\text { Recovery } \\
\text { Room }\end{array}$ & & & \\
\hline 13.00 & $\begin{array}{l}\text { Setelah pasien } \\
\text { masuk di } \\
\text { Recovery } \\
\text { Room, } \\
\text { selanjutnya } \\
\text { dilakukan } \\
\text { pemasangan } \\
\text { alat } \\
\text { monitoring } \\
\text { Pasien dapat } \\
\text { dibangunkan } \\
\text { dan } \\
\text { memonitoring } \\
\text { keadaan } \\
\text { pasien selama } \\
2 \text { jam post } \\
\text { operasi. } \\
\text { Menilai skor } \\
\text { aldrete, bila } \\
\text { skor 10 pasien } \\
\text { dapat } \\
\text { dipindahkan } \\
\text { ke ruangan } \\
\text { perawatan. }\end{array}$ & $110 / 78$ & 82 & 100 \\
\hline
\end{tabular}

\section{Terapi Cairan}

1. Cairan pengganti puasa $\quad$ Pasien puasa sejak pukul 24.00 WITA Maintenance (M) - $10 \mathrm{~kg} \mathrm{I} \mathrm{:}$ $4 \mathrm{cc} / \mathrm{kgBB} / \mathrm{jam}$

$$
-10 \mathrm{~kg} \mathrm{II} \mathrm{:}
$$

$2 \mathrm{cc} / \mathrm{kgBB} / \mathrm{jam}$

III $: 1 \mathrm{cc} / \mathrm{kgBB} / \mathrm{jam}$

$$
=10 \mathrm{~kg} \mathrm{I}
$$

: 4cc/kgBB/jam x $10 \mathrm{~kg}=40 \mathrm{cc}$

$$
=10 \mathrm{~kg} \text { II }
$$

: $2 \mathrm{cc} / \mathrm{kgBB} / \mathrm{jam} \times 5 \mathrm{~kg}=10 \mathrm{cc}$

Total

$=50 \mathrm{cc} / \mathrm{jam}=17 \mathrm{tpm}$

\section{b. Instruksi Post Operasi}

- Bila kesakitan

ketorolac Injeksi 3 x $30 \mathrm{mg}$

- Infus : RL 17 tpm

- Minum/Makan ： Belum boleh

\section{PEMBAHASAN dan DISKUSI}

Dari hasil kunjungan pra anestesi baik dari anamnesis, pemeriksaan fisik akan dibahas masalah yang timbul, baik dari segi medis, bedah maupun anestesi. Pasien Perempuan 39 tahun datang ke ruang operasi untuk menjalani operasi miringiotimi pada tanggal 31 Juli 2019 dengan diagnosis otitis media eksudatif dextra. Persiapan operasi dilakukan pada tanggal 30 Juli 2019. Dari anamnesis terdapat keluhan telinga terasa tersumbat dan penurunan pendengaran pada telinga kanan. Keluhan dirasakan sudah cukup lama sekitar satu tahun belakangan. Pasien mengatakan keluhan telinga tersumbat dirasakan terus menerus setiap hari dan semakin memberat sehingga pasien merasa kurang pendengaran bahkan sampai kadang-kadang tidak dapat mendengar. Pasien mengatakan keluhan dirasakan secara tiba-tiba sekitar satu tahun yang lalu dan perlahan-lahan dirasakan semakin memberat dan mengganggu aktivitas. Pasien juga mengatakan sejak beberapa hari ini telinganya terasa nyeri yang dirasakan secara terus menerus dan mengganggu 
pasien. Pasien mengatakan keluhan tidak membaik baik saat istirahat ataupun beraktivitas. Pasien tidak pernah megalami keluhan yang sama sebelumnya. Keluhan lain seperti batuk, pilek, pusing disangkal. Pemeriksaan fisik dari tanda vital didapatkan; tekana darah 110/80 mmHg, nadi $80 x / m e n i t$; respirasi $20 x / m e n i t$; suhu 36,2OC, Vas 3. Dari pemeriksaan laboratorium yang dilakukan tanggal 30 Juli 2019 dalam batas normal. Dari hasil anamnesis, pemeriksaan fisik dan pemeriksaan penunjang disimpulkan bahwa pasien masuk dalam ASA I yaitu penyakit bedah tanpa disertai penyakit sistemik.

Sebelum dilakukan operasi pasien dipuasakan selama 8 jam. Tujuan puasa untuk mencegah terjadinya aspirasi isi lambung karena regurgitasi. Aspirasi isi lambung, penyebab, akibat dan gejalanya dapat dibedakan oleh 3 bahan aspirat yaitu berupa asam, partikel (sisa makanan) dan bakteri. Secara umum aspirasi dapat dicegah dengan mencegah isi lambung agar tidak masuk ke faring, aspirasi yang di faring dijaga tidak masuk trakhea dan paru. Selain bahan aspirat, volume isi lambung menentukan keparahan akibat aspirasi sehingga jumlah yang cairan masuk paru diupayakan menjadi lebih sedikit. Timbulnya reaksi akibat aspirasi asam dapat terlihat segera setelah kejadian atau gejala yang timbulnya lambat. Aspirasi asam lambung terjadi 2 fase yaitu trauma pada jaringan dan reaksi keradangan. Dalam waktu 5 detik, asam akan bereaksi dengan mukosa trakhea dan alveoli, dan dalam waktu 15 detik telah terjadi netralisasi. Enam jam kemudian akan kehilangan lapisan sel superfisial yang bersilia dan yang tidak bersilia. Regenerasi terjadi dalam waktu 3 hari, dan dalam waktu 7 hari terjadi regenerasi yang sempurna pada sel yang mengalami kerusakan. Sel alveolar tipe II sangat peka terhadap asam hidroklorid dan mengalami kerusakan dalam waktu 4 jam setelah terjadinya aspirasi. Peningkatan lisophophosphatidyle choline yang cepat dalam 4 jam setelah aspirasi asam mengakibatkan peningkatan permiabilitas alveolar dan cairan paru (lung water). Peningkatan cairan paru mengakibatkan menurunkan compliance paru, menurunkan kemampuan perfusi-ventilasi paru. Pada fase kedua, ditandai dengan pelepasan sitokin sitokin inflamasi yag terangsang dengan adanya zat asam seperti TNF $\alpha$ dan interleukin-8. Hal ini akan merangsang ekspresi sel adhesion molecule L-selectin dan beta-2 integrins pada neutrofil, and intercellular adhesion molecules (ICAM) pada endothel paru yang selanjutnya merangsang reaksi peradangan (neutrophilic inflammatory response)., (Ting, H. 2002).

Akibatnya memicu reaksi
peradangan yang menyeluruh yang
memungkinan terjadinya kegagalan


kardiopulmoner. Aspirasi isi lambung secara bersamaan menyebabkan terjadi fokus peradangan dan reaksi tubuh terhadap benda asing dengan kerusakan jaringan secara menyeluruh akibat asam. Partikel dan asam lambung bekerja sama secara sinergis menyebabkan kebocoran kapiler alveolar. Aspirasi partikel besar dari isi lambung, akan menimbulkan gejala obstruksi jalan napas, dan dalam waktu pendek dapat terjadi kematian pasien, oleh karena itu partikel tersebut harus segera dikeluarkan, dan dilakukan oksigenasi dan ventilasi untuk menghindari hipoksia, dan segera dilakukan intubasi untuk mencegah aspirasi selanjutnya. Isi lambung tidak steril sehingga aspirasi yang terjadi dapat disertai bakteri. $60-100 \%$ terdiri dari kuman anaerob. Gabungan kuman aerob dan anaerob sering dijumpai pada aspirasi pneumoni yang terjadi di rumah sakit. Pseudomonas Aeroginosa, Klebsiella dan Escheresia Colli merupakan kuman gram negatif yang banyak dijumpai sebagai penyebab Pneumonia Nosokomial. Staphylococcus Aureus merupakan kuman gram positif yang patogen. Kuman gram negatif yang dijumpai pada pemakaian ventilator, $34 \%$ berasal dari aspirasi isi lambung dan sekret orofaring, dan diduga merupakan penyebab kematian pneumonia pasca bedah. Penggantian puasa juga harus dihitung dalam terapi.

Pemilihan teknik anestesi pada
Pemilihan teknik anestesi pada pasien adalah anastesi umum dengan pemasangan Laryngeal Mask Airway. Alasan pemilihan teknik anestesi ini berdasarkan indikasi sebagai berikut :

- Lokasi pembedahan pada daerah kepala (telinga).

- Posisi pasien saat operasi adalah terlentang

- Induksi dan pemeliharaan anestesi pada pembedahan cukup lama

- Manipulasi yang dilakukan yaitu manipulasi liang telinga.

- Jenis kelamin pasien, dimana perempuan memiliki tingkat kecemasan yang lebih besar dari lakilaki.

- Pada pemeriksaan fisik dan penunjang diketahui keadaan pasien baik

Pasien masuk ke ruang operasi pada pukul 11.30 WITA dilakukan pemasangan monitoring tekanan darah, nadi, saturasi, dengan hasil tekanan darah 120/80 mmHg, nadi 80x/menit, dan SpO2 100\%. Pada pasien ini, urutan tindakan anastesi dimulai dari preoperatif, intraoperatif, dan postoperatif.

Pasien diberikan obat-obat premedikasi bertujuan untuk menimbulkan rasa nyaman bagi pasien, mengurangi sekresi kelenjar dan menekan refleks vagus, memperlancar induksi, mengurangi dosis obat anestesia, mengurangi rasa sakit dan gelisah paska bedah, menimbulkan amnesia retrograde 
Pada pasien ini, obat-obatan yang dipilih adalah sebagai berikut :

\section{Premedikasi}

Analgesik : Ketorolac injeksi $30 \mathrm{mg}$ (IV) Konsentrasi $30 \mathrm{mg} / \mathrm{ml}$ dalam dalam 1 Ampul $1 \mathrm{ml}$.

Diberikan secara intravena.Dosis untuk bolus intravena harus diberikan selama minimal 15 detik.Mulai timbulnya efek analgesia setelah pemberian IV maupun IM serupa, kira-kira 30 menit, dengan maksimum analgesia tercapai dalam 1 hingga 2 jam.Durasi median analgesia umumnya 4 sampai $6 \mathrm{jam}$. Dosis awal yang dianjurkan adalah $10 \mathrm{mg}$ diikuti dengan 10-30 mg tiap 4 sampai 6 jam bila diperlukan dosis maks 90mg/hari, pada manula, gangguan faal ginjal, dan BB $<50 \mathrm{~kg}$ dibatasi maks $60 \mathrm{mg} /$ hari. Efek pemberian obat ini yaitu menghambat biosintesis prostaglandin di perifer tanpa mengganggu reseptor opioid di sistem saraf pusat dimana mekanisme kerjanya menghambat enzim siklooksogenase (COX 1). Selain menghambat sintese prostaglandin, juga menghambat tromboksan A2 sehingga memiliki efek anti inflamasi. Pada pasien ini diberikan ketorolac injeksi $30 \mathrm{mg}$ IV dengan tujuan untuk mendapatkan efek analgesia yang terkandung dalam ketorolac sehingga dapat mengurangi nyeri pada pasien., (Dachlan M, R. 2009).

Antiemetik : Ondancentron injeksi $4 \mathrm{mg}$ (IV).
Konsentrasi $4 \mathrm{mg} / 2 \mathrm{ml}$ dalam 1 Ampul $2 \mathrm{ml}$, dosis 0,05-01 mg/kgBB Ondansentron, sebagai anti emetik, suatu antagonis selektif 5-HT3, menghambat serotonin dan bekerja berdasarkan mekanisme sentral dan perifer. Mekanisme sentral dengan mempertinggi ambang rangsang muntah di chemoreceptor trigger zone. Mekanisme perifer dengan menurunkan kepekaan saraf vagus terminalis di visceral yang menghantar impuls eferen dari saluran cerna ke pusat muntah.Onset 30 menit, dengan durasi 3 jam.Pada pasien ini diberikan ondancentron $4 \mathrm{mg}$ (IV) untuk mendapatkan efek emetik sehingga pasien tidak merasakan mual ataupun muntah saat dilakukan induksi operatif ataupun pasca operatif., (Brunton LL.2008).

Ranitidine : injeksi 50 mg (IV) Konsentrasi $50 \mathrm{mg} / 2 \mathrm{ml}$ dalam 1 ampul 2 $\mathrm{ml}$, dosis $1-2 \mathrm{mg} / \mathrm{kgBB}$.

Efek pada Gastrointestinal, ranitidine bekerja dengan menghambat secara kompetitif reseptor histamin $\mathrm{H} 2$ menghambat kerja histamin secara kompetitif pada reseptor $\mathrm{H} 2$ dan mengurangi sekresi asam lambung.Dosis intravena intermiten atau intramuskular pada dewasa adalah $50 \mathrm{mg}$ setiap 6-8 jam.Jika perlu dosis dapat dapat ditingkatkan dengan meningkatkan frekuensi pemberian, namun tidak boleh melebihi $400 \mathrm{mg}$ perhari.Pada pasien ini diberikan ranitidine injeksi $50 \mathrm{mg}$ (IV) 
untuk mendapatkan mencegah agar tidak terjadinya aspirasi ke paru - paru., (Brunton LL. 2008).

\section{Induksi}

Fentanyl : injeksi 100 mcg (IV)

Konsentrasi 0,05 mg/ml dalam 1 ampul 2 $\mathrm{ml}$, dosis $12 \mathrm{mcg} / \mathrm{kgBB}$

Fentanyl, golongan obat opioid analgetik poten yang terutama bekerja sentral pada sistem saraf pusat, sehingga mengakibatkan meningkatnya ambang batas nyeri, mengurangi persepsi nyeri menghambat serabut saraf nyeri ascending, menyebabkan depresi nafas dan sedasi.Pada dosis lazim kesadaran pasien menurun dan khasiat analgetiknya yang kuat.Onset 30-120 detik dengan durasi 30-60 menit. Dosis 1-2 mcg/kgBB IV. Tujuan dari pemberian fentanyl adalah untuk meningkatkan kualitas analgesia intraoperative dan dapat menghasilkan onset 1 sampai 2 menit dan dari analgesia berdurasi 30 menit sampai 1 jam. (Chandra S, 2012)

Propofol : injeksi $100 \mathrm{mg}$ (IV) Konsentrasi $10 \mathrm{mg} / \mathrm{ml}$ dalam 1 ampul berisi $20 \mathrm{ml}$, dosis pemberian 22,5mg/kg/BB.

Propofol dianggap memiliki efek sedative hipnotik melalui interaksinya dengan reseptor GABA dengan cara meningkatkan GABA. Pada pemberian dosis induksi (2 $\mathrm{mg} / \mathrm{kgBB}$ ), pemulihan kesadaran berlangsung cepat, pasien akan bangun 4-5 menit tanpa disertai efek samping. Khasiat farmakologinya adalah hipnotik murni, tidak mempunyai efek analgetik maupun relaksasi otot., (Chandra S, 2012).

Walaupun terjadi penurunan tonus otot rangka, hal ini disebabkan oleh efek sentralnya Induksi anestesia 2,0-2,5 $\mathrm{mg} / \mathrm{kgBB}$. Pada bayi dan lansia dosis disesuaikan.Pasien tua memerlukan dosis induksi lebih rendah 25\% - 50\% dari dosis lazim., (Chandra S, 2012).

Pemasangan LMA pada pasien dilakukan berdasarkan indikasi yang telah disebutkan di atas. Untuk pemasangan LMA membutuhkan kedalaman anastesi yang lebih besar. Pada pasien tersebut diberikan propofol dengan dosis 150mg untuk mencapai kedalaman anastesi yang optimal. Selama operasi berlangsung dilakukan pemantauan tanda vital berupa tekanan darah, nadi, dan saturasi oksigen setiap 5 menit secara efisien dan terus menerus, dan pemberian cairan intravena berupa RL. Cairan yang diberikan adalah RL (Ringer Laktat) karena merupakan kristaloid dengan komposisinya yang lengkap ( $\mathrm{Na}+, \mathrm{K}+, \mathrm{Cl}-, \mathrm{Ca}++$, dan laktat) yang mengandung elektrolit untuk menggantikan kehilangan cairan selama operasi, juga untuk mencegah efek hipotensi akibat pemberian obat-obatan intravena dan gas inhalasi yang mempunyai efek vasodilatasi., (Katzung, 2002).

Pada pasien ini diberikan 
Pada pasien ini diberikan maintanance $\mathrm{O} 2: \mathrm{N} 2 \mathrm{O}:$ sevofluran $=40$ : $60: 2 \mathrm{vol} \%$ secara inhalasi dalam kasus ini yaitu face mask dengan tujuannya yaitu untuk memperpanjang durasi obat induksiagar terpenuhinya trias anestesia yaitu hipnotik analgesia dan relaksasi otot.

Selama operasi keadaan pasien stabil. Setelah operasi selesai, selanjutnya melakukan ekstubasi saat pasien tidak sadar dengan memperhatikan syarat ekstubasi: nafas adekuat, hemodinamik stabil, saturasi, volume tidal.Jika syarat terpenuhi, keluarkan udara dari cuff dan mengeluarkan OTT, kemudian memasang goedel (oral airway)dan gas N2O dan Sevoflurane dimatikan, dan gas O2 dinaikkan menjadi 6\% (oksigenasi) dengan menggunakan face mask.Serta melihat saturasi pasien, melihat dada pasien baik atau tidak dalam bernapas.Menilai skor aldrete, bila skor $\geq 8$ pasien dapat dipindahkan ke ruangan perawatan.

Gas O2 dihentikandan observasi dilanjutkan pada pasien di recovery room, dimana dilakukan pemantauan tanda vital meliputi tekanan darah, nadi, respirasi dan saturasi oksigen dan menghitung aldrete score.15,16.

\section{Post Operasi Terapi Analgetik}

Pada pasien ini diberikan : Ketorolac 3x30 mg. Pemberian analgetik post operasi pasien tersebut pada pasien ini digolongkan sebagai nyeri akut berdasarkan WFSA Analgesic Ladder dimana pada awal pemberian obat dimulai dari injeksi opioid kuat, analgesik lokal, dan NSAIDs dengan NRS pasien 3 sehingga pada pasien ini menggunakan analgetik NSAIDs., ( Katzung, 2002).

Ketorolac merupakan obat antiinflamasi nonsteroid (NSAIDs). Ketorolac $60 \mathrm{mg}$ diberikan secara intravena. Mulai timbulnya efek analgesia setelah pemberian IV maupun IM serupa, kira-kira 30 menit, dengan maksimum analgesia tercapai dalam 1 hingga 2 jam.Durasi median analgesia umumnya 4 sampai 6 jam. Dosis awal yang dianjurkan adalah $10 \mathrm{mg}$ diikuti dengan $10-30 \mathrm{mg}$ tiap 4 sampai 6 jam bila diperlukan dosis maks 90mg/hari, pada manula, gangguan faal ginjal, dan BB <50kg dibatasi maks $60 \mathrm{mg} /$ hari. Efek pemberian obat ini yaitu menghambat biosintesis prostaglandin di perifer tanpa mengganggu reseptor opioid di sistem saraf pusat dimana mekanisme kerjanya menghambat enzim siklooksogenase (COX 1). Selain menghambat sintese prostaglandin, juga menghambat tromboksan A2 sehingga memiliki efek anti inflamasi., (Brunton LL.2008).

\section{Terapi PONV (Postoperative Nausea and Vomiting).}

Salah satu efek samping yang sering terjadi setelah tindakan anastesi umum yakni mual dan muntah. Pada pasien ini, pasca operasi mengeluh mual dan muntah 
lebih dari 5 kali. Pasien mengeluh mual dan muntah lebih terasa jika melakukan perubahan posisi. Pada kondisi ini pasien diberikan Ondasentron $4 \mathrm{mg} \mathrm{k} / \mathrm{p}$. Setelah 2 jam pemberian Ondasentron $4 \mathrm{mg}$ iv, pasien mengaku keluhan mual dan muntah sudah berkurang. Hal ini sebanding dengan literatur dimana prosedur pada telinga tengah sering menyebabkan mual dan muntah, Karena telinga mempunyai bagian erat yang terlibat dengan keseimbangan. Operasi telinga dapat menyebabkan pusing (vertigo) pascaoperasi dan mual pasca operasi dan muntah (PONV). Banyak obat yang terbukti efektif, termasuk infus propofol, Granisetron, Transdermal Scopolamine, Ondansetron, Droperidol, dan Eliminasi N2O. PONV dapat dikontrol dengan dosis iv obat potensial antiemesis (contoh droperidol, 0,01/kg: ondansetron, 0,05 $\mathrm{mg} / \mathrm{kg}$; atau dolasetron, $0,20 \mathrm{mg} / \mathrm{kg}$ ) diberi selama pembedahan., ( Brunton LL.2008).

\section{KESIMPULAN}

Otitis Media Efusi (OME) adalah suatu penumpukan cairan dalam telinga tengah dengan membrane timpani yang masih utuh tanpa disertai tanda-tanda infeksi akut. Adanya cairan di dalam telinga tengah mengakibatkan terjadinya gangguan pendengaran.

Dalam banyak kasus OME merespon merespon antibiotik, namun infeksi berulang biasanya memerlukan operasi, yang memerlukan pembuatan sebuah lubang di gendang telinga (miringotomi) untuk mengurangi tekanan dan mengalirkan sekresi telinga tengah. Anestesi umum, contoh dengan Laryngeal Mask Airway, cukup memuaskan. Sebuah tekanan kecil penyama logam (equalizing metal) atau tabung plastik (plastic tube) umumnya dimasukkan untuk menjaga lubang terbuka dan mencegah akumulasi cairan. Tabung ini berada di lubang tersebut selama enam bulan dan akan terlepas secara spontan.

Pemilihan teknik anestesi pada pasien ini adalah anastesi umum dengan pemasangan laryngeal mask airway. Alasan pemilihan teknik anestesi ini berdasarkan lokasi pembedahan, posisi pasien saat operasi, induksi dan pemeliharaan anestesi, dan manipulasi.

\section{DAFTAR PUSTAKA}

Dorland, Newman W., 2012, Kamus Saku Kedokteran Dorland Edisi 28, EGC: Jakarta.

Mangku, Gde., Senapathi, Tjokorda, Gde, Agung. 2017. Buku Ajar Ilmu Anestesi dan Renimasi. Penerbit PT. Macan Jaya Cemerlang: Jakarta.

Robinson DH, Toledo AH. Historical development of modern anesthesia. 2012.

Olutoyin O.A.George. Anesthesia for ear, nose, and throat (ENT) surgery. Chapter17.p(469-470).Anesthesia Care of Pediatric patient.2014.

Donlon JV. Anesthesia for eye, ear, nose, and throat surgery. In: Miller RD, ed. Anesthesia. 5th ed. New York: 
Churchill Livingston. 2000.p(217398).

David EL, David LB. Anesthesia for Otorhinolaryngologic (Ear, Nose, Throat) Surgery. Anesthesiology. 2nd. 2012.

Latief S, A., Suryadi K, A., Dachlan M, R. 2009. Petunjuk Praktis Anestesiologi Edisi Kedua. Penerbit Bagian Anestesiologi dan Terapi Intensif FKUI: Jakarta.

Moore KL. 2002. Anatomi klinis dasar. Dalam. Jakarta: EGC.

Ting,H.Paul. Intravenous Anesthetic. Available at.

Soenarto RF, Chandra
S. Buku ajar
anestesiologi.Jakarta:Departemen
anestesiologi dan intensive care RS
Cipto
Mangunkusumo;2012.h.197-207.
Katzung BG..Basic \& clinical
pharmacology.10th ed.USA : The
McGraw-Hill Companies; 2007.

Brunton LL, Parker

KL.Goodman\&gillman :manual of pharmacology and therapeutics. USA : The McGraw-Hill Companies;2008.

Beauchamp, Evers, Mattox. Sabiston textbook of surgery.19th

ed.Canada:Elsevier;2012. 